\title{
Potential of wormwood (Artemisia absinthium) as a feed supplement in rabbit diet: effect on controlling rabbit coccidiosis, antioxidative systems and growth performance
}

\author{
Sanja J. Popović1*, Ljiljana M. Kostadinović ${ }^{1}$, Nikola M. Puvača ${ }^{2}$,

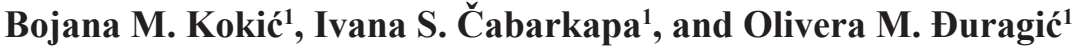 \\ ${ }^{1}$ Institute of Food Technology, University of Novi Sad, Novi Sad, Serbia \\ ${ }_{2}^{2}$ Patent Co. DOO, Mišićevo, Serbia
}

POPOVIĆ, S. J., LJ. M. KOSTADINOVIĆ, N. M. PUVAČA, B. M. KOKIĆ, I. S. ČABARKAPA, O. M. ĐURAGIĆ: Potential of wormwood (Artemisia absinthium) as a feed supplement in rabbit diet: effect on controlling rabbit coccidiosis, antioxidative systems and growth performance. Vet. arhiv 87, 769-782, 2017.

\section{ABSTRACT}

The objective of the study was the investigation of dietary inclusion of Artemisia absinthium as a potential anticoccidial drug in rabbit diet, as well as a growth promoter and antioxidant in rabbit nutrition. The in vivo investigation was carried out on 120 male New Zealand white rabbits. The rabbits were distributed into four dietary treatments with ten replicates each. Two levels of whole wormwood plant were used: $100 \mathrm{~g} / \mathrm{kg}$ (WW100) and $200 \mathrm{~g} / \mathrm{kg}$ (WW200). The control treatment (C) was basal diet, and one treatment $(\mathrm{CR})$ received chemical coccidiostat robenidine, supplemented in the amount of $6 \mathrm{~g} / \mathrm{kg}$. The rabbits were given ad libitum access to water and feed throughout the entire trial period. Feed intake was measured on a daily basis, while body weight was monitored at an individual level during the entire experimental period every seven days, for a total of 77 days. Blood and liver samples were collected for enzyme analyses, where oocyst counts were determined in $1 \mathrm{~g}$ of rabbit feces. At the end of the trial, the addition of $200 \mathrm{~g} / \mathrm{kg}$ of wormwood led to the highest body weight $(3047 \mathrm{~g})$, as well to the lowest feed conversion ratio $(3.20 \mathrm{~kg} / \mathrm{kg})$ with significant differences compared to the control treatment $(3.75 \mathrm{~kg} / \mathrm{kg})$. The highest recorded glutatione reductase value was with treatment WW100, with significant differences to other experimental treatments. Consumption of coccidiostat and dried wormwood plant in different levels led to a notably lower malondialdehyde content in liver homogenate compared to the control treatment. Finally, the lowest number of oocysts was found in the treatment receiving wormwood in a concentration of $100 \mathrm{~g} / \mathrm{kg}$. On the basis of the results achieved, it may be noticed that wormwood supplementation in the diet of rabbits has a positive influence on growth performance, as well on antioxidative systems in rabbits. Subsequently, it was shown that wormwood can successfully be used in reducing the number of oocysts in rabbits.

Key words: antioxidative system, coccidiosis, growth performance, rabbit, wormwood

\footnotetext{
*Corresponding author:

MSc Sanja Popović, University of Novi Sad, Institute of Food Technology, Bulevar cara Lazara 1, Novi Sad, Serbia, Phone: +381 21485 3775, E-mail: sanja.popovic@fins.uns.ac.rs
} 
S. J. Popović et al.: Artemisia absinthium: promising feed supplement in rabbits nutrition

\section{Introduction}

Coccidiosis is a contagious sporozoal infection of the intestine, but hepatitic coccidiosis is also possible (PAKANDL, 2009). Coccidiosis, caused by the Eimeria species, results not only in enormous economic losses in rabbit farming, when mortality rate may be between 12 and $20 \%$, and may reach up to $50 \%$ mainly in rabbits at 4 to 8 weeks of age (RASHWAN and MARAI, 2000), but it is also responsible for a decrease in daily increment, prolonged fattening, poorer skin pigmentation, slower feed conversion and increased mortality (LI and OOI, 2008).

In the last decade the use of antibiotics, such as sulfonamides as well as salinomycin and robenidine, which are mainly used in rabbit nutrition for the treatment of coccidiosis, has been questioned. The increasing resistance of avian coccidia (protozoa) to anticoccidial drugs currently used by the animal industry has stimulated the search for new alternatives in solving such disease problems (KOSTADINOVIĆ et al., 2014). Subsequently, the ban on antibiotics in 2006 for use in animal nutrition due to the emergence of microbe resistance, has led to an intensive search for alternative solutions (STEINER, 2009) which are safer and more environmentally friendly.

Medicinal plants have recently been reported as potential alternatives to anticoccidial drugs since they have been found to be effective for a broad range of parasites, such as protozoa, arthropods and helminthes (KOSTADINOVIĆ et al., 2014; ROJHAN, 2000). Artemisia absinthium, known as wormwood, from the family Compositae (Asteraceae), is one of 300 species from this genus. The essential oil composition of this plant showed that its active substances include silica, two bitter substances (absinthin and anabsinthine), thujone, tannic, resinous substances, malic acid, and succinic acid (HABIBI et al., 2016). The essential oil obtained from wild plant wormwood shows antibacterial, antifeedant, antipyretic, fertility increasing, cytostatic and antimalarial activities (KOSTADINOVIĆ et al., 2014) and stimulates the digestion process (LANGHOUT, 2000). Therefore, medical herbs used in animal nutrition may have promising potential as growth and health promoters, without any adverse effects (PUVAČA et al., 2015; KOSTADINOVIĆ et al., 2014).

Increases in the level of reactive oxygen species (ROS), which are formed by living organisms as a result of normal cellular metabolism (BIRBEN et al., 2012), may lead to oxidative destruction of cells, known also as an 'oxidative stress' (MITTLER, 2002). As a consequence of oxidative stress, numerous pathological changes, such as membrane dysfunction, DNA damage, inactivation of proteins, and also cancer, arthritis and neurodegenerative disease, may occur in humans, but also in animal organisms (HAYES and McLELLAN, 1999). However, aerobic organisms possess highly effective protective systems from free radicals which consist of enzymatic and nonenzymatic antioxidants that are usually effective in blocking the harmful effects of ROS (BIRBEN et al., 2012). 


\section{S. J. Popović et al.: Artemisia absinthium: promising feed supplement in rabbits nutrition}

The liver is an organ with a central metabolic role in the organism, known as 'the main laboratory' since it performs the major detoxification tasks (KOSTADINOVIĆ et al., 2015). Hence, various mechanisms of protection are involved during the defensive processes. Antioxidant enzymes prevent the excessive and harmful effects of reactive oxygen. For instance, superoxide dismutase (SOD) catalyzes the conversion of superoxide anion radical to $\mathrm{H}_{2} \mathrm{O}_{2}$ and reduction of $\mathrm{H}_{2} \mathrm{O}_{2}$ to water, while glutathione peroxidase (GSHPx) acts in conjunction with other enzymes to reduce $\mathrm{H}_{2} \mathrm{O}_{2}$ and to terminate lipid peroxidation (HALLIWELL and CHIRICO, 1993). Also, glutathione (GSH) plays an important role in the reduction of acute toxicity of xenobiotics and products of lipid peroxidation as a substrate for GSHPx, and can be regenerated by the enzyme glutathione reductase (GR). Lipid peroxidation is the process in which free radicals 'steal' electrons from the lipids in cell membranes, resulting in cell damage. It most often affects polyunsaturated fatty acids, since they contain multiple double bonds, between which there are methylene bridges (-CH2-) that possess especially reactive hydrogens, leading to formation of lipid peroxides such as malondialdehyde (MDA) and hydroxyl, and hence, resulting in tissue or cell damage (OSTALOWSKA et al., 2006). For this reason, MDA content plays a major role as an indicator of the lipid peroxidation level, and as an indirect reflection of the level of cell damage.

The study was conducted in order to evaluate the in vivo efficacy of different doses of wormwood in lowering the number of eimerian oocysts in New Zealand White rabbits, the antioxidant efficacy, as well as growth promoter efficacy of a rabbit diet supplemented with wormwood.

\section{Materials and methods}

Pre-experimental investigation. Before the experimental trial, the symptoms of naturally infected animals were noticed in rabbits and subsequently recorded daily. All rabbits were found to be infected with Eimeria species in view of the increased mortality rate and bloody diarrhea which was confirmed on the basis of fecal examination.

The direct smear and the saturated sugar floatation technique were used for determining the presence and identification of eimerian oocysts (SOULSBY, 1982). The number of coccidial oocysts per gram (OPG) of feces were determined using the McMaster technique. Samples of the livers of dead rabbits were collected and examined for gross lesions, whereby the liver tissues were used for histopathological examination.

Collection and processing of plant materials. The plant used for this study was wormwood (Artemisia absinthium). The stem bark of the plants was collected in April and May 2014 from The Institute for Medicinal Plant Research 'Dr Josif Pančić', Belgrade. The stem bark of the plants was dried under shade for 10 days at $8 \mathrm{~h}$ per day, ground into powder and stored for later use in the study. 
Experimental design. Experiments under in vivo conditions were performed on 120 seven-week-old male New Zealand white rabbits which were naturally contaminated by the Eimeria species, as mentiond above, with an initial body weight of 1050-1200 g. Infected rabbits were randomly divided into four dietary treatments. Each treatment consisted of 10 replicates of three rabbits housed in one cage according to the experimental design given in Table 1. Two levels of whole wormwood plant were applied: $100 \mathrm{~g} / \mathrm{kg}$ (WW100) and $200 \mathrm{~g} / \mathrm{kg}$ (WW200). The control treatment (C) was a basal diet (Table 2), and one treatment (CR) received chemical coccidiostat robenidine, supplemented in the amount of $6 \mathrm{~g} / \mathrm{kg}$. The rabbits were fattened from 7 to 17 weeks of age. They were housed at room temperature $\left(22 \pm 2{ }^{\circ} \mathrm{C}\right)$ and with a $12 \mathrm{~h}$ light/dark cycle (lights on: 08:00-20:00 h), in wire mesh cages, which were cleaned daily. The rabbits were fed using a standard basal diet with access to water and feed ad libitum.

Table 1. Experimental design

\begin{tabular}{|l|c|c|c|c|}
\hline & \multicolumn{4}{|c|}{ Treatment } \\
\hline Additive & C & CR & WW100* & WW200* \\
\hline $\begin{array}{l}\text { Concentration of additive } \\
\text { in rabbits diet }(\mathrm{g} / \mathrm{kg})\end{array}$ & None & $\begin{array}{c}\text { Coccidiostat } \\
\text { robenidine }\end{array}$ & Wormwood & Wormwood \\
\hline
\end{tabular}

* Medical herb is added on top on the basic diet; C-Control treatment; CR-robenidine treatment; WW100wormwood treatment with addition of $100 \mathrm{~g} / \mathrm{kg}$ of dry herb; WW200-wormwood treatment with addition of $200 \mathrm{~g} / \mathrm{kg}$ of dry herb

Body weight gain, feed intake and feed conversion ratio. Each rabbit was weighed weekly from weaning to 119 days of age, while feed intake was measured on a daily basis. Daily feed intake and daily weight gain were subsequently calculated. The feed conversion ratio was calcuated as the ratio between daily feed intake and daily body weight gain.

Table 2. Chemical composition of the basal diet

\begin{tabular}{|l|c|}
\hline Ingredient & $\%$ \\
\hline Proteins & 15.0 \\
\hline Moisture & 13.5 \\
\hline Cellulose & 14.0 \\
\hline Ash & 8.00 \\
\hline $\mathrm{Ca}$ & 1.00 \\
\hline $\mathrm{P}$ & 0.75 \\
\hline $\mathrm{Na}$ & 0.25 \\
\hline
\end{tabular}

In 1 kg of diet: Vitamin A 8000 IU, Vitamin D3 1200 IU, Vitamin E 25 mg, Vitamin K 1 mg, Vitamin C 100 $\mathrm{mg}$, Vitamin B1 $2.5 \mathrm{mg}$, Vitamin B2 $6 \mathrm{mg}$, Vitamin B6 $3 \mathrm{mg}$, Vitamin B12 $0.02 \mathrm{mg}$, Nicotinic acid $50 \mathrm{mg}$, Pantothenic acid $15 \mathrm{mg}$, Folic acid $0.5 \mathrm{mg}$, Biotine $0.2 \mathrm{mg}$, Choline chloride $800 \mathrm{mg}$, Cu $5 \mathrm{mg}$, Fe $60 \mathrm{mg}$, Zn 60 mg, Mn 20 mg, Mg 100 mg, J 0.6 mg, Co 0.1 mg, Se 0.1 mg, Antioxidant (BHT) $100 \mathrm{mg}$. 


\section{S. J. Popović et al.: Artemisia absinthium: promising feed supplement in rabbits nutrition}

Preparation of blood hemolysates. On day 119, two rabbits from each pen (20 per treatment) were randomly selected and blood samples were collected from a marginal ear vein of rabbits that had fasted overnight. The plasma was separated by centrifugation $(3500 \mathrm{~g}, 10 \mathrm{~min})$ and stored at $-70^{\circ} \mathrm{C}$ for analysis of biochemical parameters. The remaining red blood cells (RBCs) were washed three times with isotonic $\mathrm{NaCl}(0.15 \mathrm{M})$ prior for use in the biochemical assay. $\mathrm{RBC}$ hemolysates were prepared by diluting RBCs 1:10 with ice-cold double distilled $\mathrm{H}_{2} \mathrm{O}$, shaken vigorously to force hemolysis, and stored at $-70{ }^{\circ} \mathrm{C}$ (FEBEL et al., 2008).

Preparation of liver homogenate. At the end of the trial period, the rabbits were processed after a $12 \mathrm{~h}$ feed withdrawal period. At sacrifice, the livers were rapidly removed and washed in cold $0.9 \%$ normal saline. One gram of the tissue was minced with scissors and homogenized in an ultratorax in 3 volumes of isotonic buffer $(0.05 \mathrm{M}$ Tris- $\mathrm{HCl}, 0.25 \mathrm{M}$ sucrose, $\mathrm{pH}=7.5$ ). The homogenate was filtered through gauze into ice-cold tubes and aliquoted for further analysis (CHIU et al., 1976).

Sample preparation for glutathione determination. Proteins from freshly prepared liver homogenates were separated by adding half a volume of $10 \%$ sulfosalicylic acid and centrifugated at $5000 \mathrm{~g}$, for $5 \mathrm{~min}$, at $4{ }^{\circ} \mathrm{C}$. The supernatant was stored at $4{ }^{\circ} \mathrm{C}$, without freezing, and GSH was determined within 24 hours. The GSH content in the liver homogenate was determined from the amount of sulfhydryl residues by means of Ellmann's reagent (KAPETANOVIĆ and MIEYAL, 1979).

Determination of enzymatic activity. Superoxide-dismutase (EC1.15.1.1) activity was determined by the spectrophotometric method based on the inhibition of adrenaline reduction to adrenochrome at $\mathrm{pH} 10.2$ (KOSTADINOVIĆ et al., 2001). The glutathioneperoxidase (EC 1.11.1.9) activity was determined by spectrophotometric measurement of absorbance at $412 \mathrm{~nm}$ with cumenhydroperoxide as the substrate (CHIU et al., 1976).

Activity of the glutathione-reductase (EC 1.6.4.2.) was determined from the rate of NADPH oxidation and it was monitored by measuring the absorbance at $340 \mathrm{~nm}$ (LUKASZEWICZ-HUSSAIN and MONIUSZKO-JAKONIUK, 2004). Malondialdehyde concentration in the serum was measured by the 2-thiobarbituric acid assay (SIMON et al., 1974).

Oocyst count (OPG index). The fecal samples were examined for all the rabbits before administering wormwood. In weeks 7, 12 and 17, oocyst counts per gram of rabbit feces were determined.

To estimate the coccidian infection rates, fecal samples of around $30 \mathrm{~g}$ were collected from each cage using mosquito net mesh, and the number of oocysts in ten samples per gram of feces was determined. The same procedure was repeated for each cage in each 
treatment. The samples were kept refrigerated prior to analysis. Determination of OPG and eggs per gram of feces was performed using the McMaster technique.

Statistical analyses. The mean \pm SEM values were calculated for each treatment to determine the significance of inter treatment differences. Each parameter was analyzed through analysis of variance (ANOVA) using STATISTICA 12.0 (2013). To find the difference between the dietary treatments, Fisher's LSD post-hoc test was used. Probability values lower then $\mathrm{P}<0.05$ were considered to be significant.

\section{Results}

Production performances. From Table 3 it may be concluded that the addition of wormwood plant to the diet of the rabbits led to significant $(\mathrm{P}<0.05)$ differences in body weights. At the end of the trial rabbits in treatment WW200 achieved the highest body weight with significant differences $(\mathrm{P}<0.05)$ compared to treatment $\mathrm{CR}$ and $\mathrm{C}$ (around $+2 \%$ and $+5 \%$, respectively), but without any statistically significant difference $(\mathrm{P}>0.05)$ compared to the treatment supplemented with $100 \mathrm{~g} / \mathrm{kg}$ of wormwood, indicating that the addition of wormwood in treatments WW100 and WW200 exerted the stimulating effect in rabbits.

Table 3. Evaluation of the growth performance parameters of rabbits

\begin{tabular}{|l|c|c|c|c|}
\hline \multirow{2}{*}{ Parameters } & \multicolumn{4}{|c|}{ Treatment } \\
\cline { 2 - 5 } & \multirow{2}{*}{$\mathrm{C}$} & CR & WW100 & WW200 \\
\hline Live weight 35d & $1103 \pm 24^{\mathrm{a}}$ & $1080 \pm 38^{\mathrm{a}}$ & $1092 \pm 78^{\mathrm{a}}$ & $1115 \pm 51^{\mathrm{a}}$ \\
\hline Live weight 119d & $2890 \pm 61^{\mathrm{a}}$ & $2987 \pm 32^{\mathrm{b}}$ & $3002 \pm 41^{\mathrm{c}}$ & $3047 \pm 75^{\mathrm{c}}$ \\
\hline Daily feed intake $(\mathrm{g} / \mathrm{d})$ & $75.4 \pm 3.0^{\mathrm{a}}$ & $75.9 \pm 5.0^{\mathrm{a}}$ & $77.9 \pm 2.0^{\mathrm{b}}$ & $85.4 \pm 7.0^{\mathrm{c}}$ \\
\hline Daily body weight gain $(\mathrm{g} / \mathrm{d})$ & $20.1 \pm 1.5^{\mathrm{a}}$ & $23.2 \pm 1.1^{\mathrm{b}}$ & $23.9 \pm 0.9^{\mathrm{b}}$ & $26.7 \pm 1.8^{\mathrm{c}}$ \\
\hline Feed conversion rate & $3.75 \pm 0.48^{\mathrm{c}}$ & $3.27 \pm 0.62^{\mathrm{b}}$ & $3.26 \pm 0.71^{\mathrm{b}}$ & $3.20 \pm 0.50^{\mathrm{a}}$ \\
\hline
\end{tabular}

Results are given as mean \pm standard deviation $(\mathrm{n}=10)$; ${ }^{\mathrm{a}-\mathrm{c}}$ Means within a row with no common superscript differ significantly at $\mathrm{P}<0.05$; C-Control treatment; CR-robenidine treatment; WW100-wormwood treatment with addition of $100 \mathrm{~g} / \mathrm{kg}$ of dry herb; WW200-wormwood treatment with addition of $200 \mathrm{~g} / \mathrm{kg}$ of dry herb

Addition of coccidiostat and wormwood in treatments CR and WW100 led to a significantly $(\mathrm{P}<0.05)$ lower feed intake compared to the WW200 treatment (around $-11 \%$ and $-9 \%$, respectively). Also, the highest weight gain was recorded in the WW200 treatment and it was significantly higher compared to the other treatments. The lowest recorded daily weight gain was in the control treatment, while between treatments CR and WW100 no differences $(\mathrm{P}>0.05)$ were noted.

The feed conversion ratio of rabbits in the experimental period was not uniform, and ranged between 3.20 and $3.75 \mathrm{~kg}$ of feed per $\mathrm{kg}$ of gain, with significant $(\mathrm{P}<0.05)$ 


\section{S. J. Popović et al.: Artemisia absinthium: promising feed supplement in rabbits nutrition}

differences. The addition of $200 \mathrm{~g} / \mathrm{kg}$ of dry herbs led to improvement of the feed conversion rate by a half point compared to the control.

Antioxidative systems of rabbits. In the present study the antioxidant defense system (both enzymatic and nonenzymatic) in blood hemolysates (Table 4) and liver homogenates (Table 5) of the rabbits, was investigated.

As can be seen from Table 4, the content of GSH and MDA in the blood hemolysates of the rabbits treated with wormwood showed a decrease in comparison with the control (C) and robenidine $(\mathrm{CR})$ treatments (around -1 point; $\mathrm{P}<0.05$ ), while glutathione peroxidase, superoxide-dismutase and gluthatione reductase activities significantly increased in the WW100 treatment compared to the other diets.

Table 4. Evaluation of the antioxidative systems of rabbit's blood

\begin{tabular}{|l|c|c|c|c|}
\hline \multirow{2}{*}{ Parameters } & \multicolumn{4}{|c|}{ Treatment } \\
\cline { 2 - 5 } & \multicolumn{1}{|c|}{$\mathrm{C}$} & \multicolumn{1}{c|}{ CR } & \multicolumn{1}{c|}{ WW100 } & \multicolumn{1}{c|}{ WW200 } \\
\hline GSH (nmol/mg protein) & $6.3 \pm 1.0^{\mathrm{b}}$ & $6.1 \pm 0.9^{\mathrm{b}}$ & $5.2 \pm 0.7^{\mathrm{a}}$ & $4.9 \pm 0.3^{\mathrm{a}}$ \\
\hline MDA (nmol/mL) & $0.7 \pm 0.1^{\mathrm{b}}$ & $0.6 \pm 0.1^{\mathrm{b}}$ & $0.5 \pm 0.2^{\mathrm{a}}$ & $0.5 \pm 0.1^{\mathrm{a}}$ \\
\hline GSHPx (nmol/mg protein min) & $7.4 \pm 0.6^{\mathrm{a}}$ & $8.1 \pm 0.9^{\mathrm{a}}$ & $8.4 \pm 0.2^{\mathrm{c}}$ & $8.3 \pm 0.3^{\mathrm{b}}$ \\
\hline SOD (nmol/mg protein min) & $28.9 \pm 1.7^{\mathrm{a}}$ & $68.4 \pm 2.4^{\mathrm{b}}$ & $81.4 \pm 1.1^{\mathrm{c}}$ & $70.4 \pm 1.2^{\mathrm{b}}$ \\
\hline GR (nmol/mg protein $\min )$ & $13.8 \pm 1.0^{\mathrm{a}}$ & $15.8 \pm 0.8^{\mathrm{b}}$ & $19.1 \pm 0.6^{\mathrm{c}}$ & $15.9 \pm 0.2^{\mathrm{b}}$ \\
\hline
\end{tabular}

Results are given as mean \pm standard deviation $(\mathrm{n}=10)$; ${ }^{\mathrm{ac}} \mathrm{c}$ Means within a row with no common superscript differ significantly at $\mathrm{P}<0.05$; C-Control treatment; CR-robenidine treatment; WW100-wormwood treatment with addition of $100 \mathrm{~g} / \mathrm{kg}$ of dry herb; WW200-wormwood treatment with addition of $200 \mathrm{~g} / \mathrm{kg}$ of dry herb

After completion of the experimental period, the lowest GSH contents achieved in liver homogenates were with treatments WW100 and WW200 (around -23\%; Table 5) compared to the treatments $\mathrm{CR}$ and $\mathrm{C}(\mathrm{P}<0.05)$. Treatment with the basal diet achieved the highest MDA content compared to other treatments $(\mathrm{P}<0.05)$.

Table 5. Evaluation of the antioxidative systems of rabbit's liver

\begin{tabular}{|l|c|c|c|c|}
\hline \multirow{2}{*}{ Parameters } & \multicolumn{4}{|c|}{ Treatment } \\
\cline { 2 - 5 } & $\mathrm{C}$ & $\mathrm{CR}$ & WW100 & WW200 \\
\hline GSH (nmol/mg protein) & $0.9 \pm 0.2^{\mathrm{c}}$ & $0.8 \pm 0.5^{\mathrm{b}}$ & $0.7 \pm 0.3^{\mathrm{a}}$ & $0.6 \pm 0.9^{\mathrm{a}}$ \\
\hline MDA (nmol/mL) & $2.7 \pm 0.4^{\mathrm{b}}$ & $1.6 \pm 0.4^{\mathrm{a}}$ & $1.5 \pm 0.9^{\mathrm{a}}$ & $1.7 \pm 0.7^{\mathrm{a}}$ \\
\hline GSHPx (nmol/mg protein $\min )$ & $4.3 \pm 0.7^{\mathrm{a}}$ & $4.6 \pm 0.8^{\mathrm{b}}$ & $5.2 \pm 0.1^{\mathrm{c}}$ & $4.7 \pm 0.2^{\mathrm{b}}$ \\
\hline SOD $(\mathrm{nmol} / \mathrm{mg}$ protein $\min )$ & $8.7 \pm 0.8^{\mathrm{a}}$ & $9.2 \pm 1.5^{\mathrm{b}}$ & $11.8 \pm 0.2^{\mathrm{c}}$ & $11.1 \pm 0.5^{\mathrm{c}}$ \\
\hline GR $(\mathrm{nmol} / \mathrm{mg}$ protein $\min )$ & $25.7 \pm 2.0^{\mathrm{a}}$ & $29.6 \pm 0.9^{\mathrm{b}}$ & $31.7 \pm 1.7^{\mathrm{c}}$ & $29.8 \pm 2.1^{\mathrm{b}}$ \\
\hline
\end{tabular}

Results are given as mean \pm standard deviation $(\mathrm{n}=10)$; ${ }^{\text {acc }}$ Means within a row with no common superscript differ significantly at $\mathrm{P}<0.05$; C-Control treatment; CR-robenidine treatment; WW100-wormwood treatment with addition of $100 \mathrm{~g} / \mathrm{kg}$ of dry herb; WW200-wormwood treatment with addition of $200 \mathrm{~g} / \mathrm{kg}$ of dry herb 
Like blood hemolysates, GSHPx, GR and SOD activities in the liver were systematically higher with the addition of wormwood in treatment WW100 $(\mathrm{P}<0.05)$. There was no difference in GSHPx activity between the treatments treated with commercial coccidostat and the rabbits receiving $200 \mathrm{~g} / \mathrm{kg}$ of wormwood. Furthermore, SOD activity was the same for the two levels of Artemisia absinthium.

Finally, it was noticed that the content of GSH in the blood and liver samples of rabbits treated with wormwood showed a significant decrease $(\mathrm{P}<0.05)$ in comparison with the control and robenidine treatments. The same tendency was recorded for MDA content. GSHPx activity in both samples was the highest in the WW100 treatment, and was statistically significantly different $(\mathrm{P}<0.05)$ from the other treatments. A similar tendency was observed in the activities of SOD and GR in the blood and liver samples of rabbits, where the highest values were recorded in the treatments receiving $100 \mathrm{~g} / \mathrm{kg}$ of wormwood with a significant difference $(\mathrm{P}<0.05)$ in comparison with the control and robenidine treatments.

Oocysts counts. The addition of wormwood to the diet of rabbits led to statistically significant $(\mathrm{P}<0.05)$ differences in the number of oocysts per gram of feces (Fig. 1).

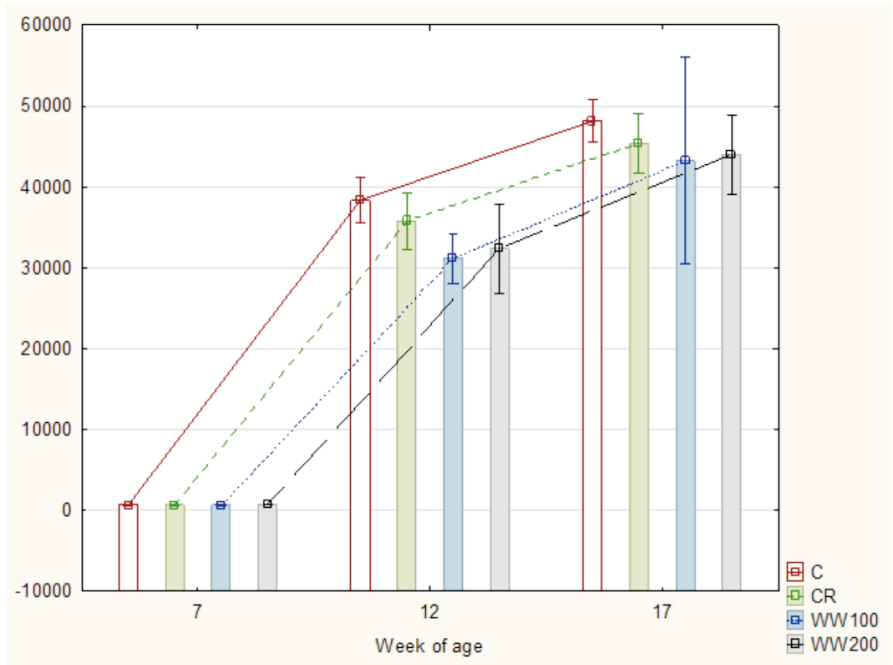

Fig. 1. Coccidiosis oocyst counts in rabbits fecal samples (number of oocyst per gram of feces). C-Control treatment; CR-robenidine treatment; WW100-wormwood treatment with addition of $100 \mathrm{~g} / \mathrm{kg}$ of dry herb; WW200-wormwood treatment with addition of $200 \mathrm{~g} / \mathrm{kg}$ of dry herb

At the beginning of the study, there was no statistically significant difference in the OPG between the rabbits (mean of 707 OPG; $\mathrm{P}>0.05$ ). Later, the level of contamination by oocystes in the $\mathrm{C}$ treatment was systematically higher compared to the other treatments 


\section{S. J. Popović et al.: Artemisia absinthium: promising feed supplement in rabbits nutrition}

$(\mathrm{P}<0.05)$, while there was no significant difference between treatments WW100 and WW200.

Finally, at the end of the experimental period, the lowest number of oocysts achieved was with treatment WW100 (40815 oocysts per g of feces) followed by treatments WW200 (43968 oocysts per $g$ of feces) and CR (45338 oocysts per $g$ of feces).

\section{Discussion}

The present investigation represents a novelty in field of betel against coccdiosis in rabbits, since to the best of our knowledge there are no relevant data in the available literature on the effects of wormwood (Artemisia absinthium) in rabbits, but mostly in chickens. Therefore, the discussion will present our findings compared with other available published works related to coccidiosis.

The results obtained indicate that the addition of wormwood powder to rabbit diet has numerous positive effects on rabbit health. The reported results from this study showed that the inclusion of wormwood in rabbit diet produced better growth performance, including higher live weight and lower feed conversion ratio. According to PUVAČA et al. (2015) a lower feed conversion ratio shows that the addition of medicinal plants and spices has a positive influence on feed utilization and efficiency. However, the research by IQBAL et al. (2013) does not agree with the results obtained in this study, revealing that the inclusion of ethanolic extract of Artemisia absinthium at level of $2 \mathrm{~g} / \mathrm{kg} \mathrm{BW}$ in the diet of goat kids resulted in slightly lower body weights compared to commercial products. From this it may be inferred that the inclusion of dried wormwood whole plant in rabbit diet was satisfactorily acceptable without any adverse effects.

Antioxidant enzymes, such as glutathione peroxidase and superoxide dismutase, have the capacity to break down free-radical reactions using a chain reaction mechanism (BENZIE, 2003). Glutathione and glutathione peroxidase are among the major antioxidant defenders, wherein GSH plays a major role in reduction of the acute toxicity of xenobiotics and products of lipid peroxidation as a substrate for GSHPx (MAK et al., 1996). Subsequently, with the increased risk of lipid peroxidation in the liver, there is an increase in the enzymatic activity of GSHPx. Depletion of GSH, causes the cells to be more resistant to free radical toxicity, indicating that GSH is involved in the reduction. In this study, the GSH concentration in both types of samples, blood hemolysates and liver homogenates, was the highest in the control group, compared to the other experimental groups. Hence, the decrease in GSH levels in the experimental treatments is an indication that detoxification is active in the organism. SOD enzyme catalyzes the dismutation of superoxide radicals into hydrogen peroxide $\left(\mathrm{H}_{2} \mathrm{O}_{2}\right)$ and molecular oxygen $\left(\mathrm{O}_{2}\right)$, and consequently represents an important defense mechanism against superoxide radical toxicity (ASSADY et al., 2011). Hence, SINGH et al. (2011) reported that an increase in 


\section{S. J. Popović et al.: Artemisia absinthium: promising feed supplement in rabbits nutrition}

catalytic activity of superoxide-dismutase is expected as part of the system defense. KOSTADINOVIĆ et al. (2015) showed that addition of Artemisa absinthium to broiler diet led to higher SOD activity in hemolysed blood and liver homogenates, which was also in agreement with the results reported by OLANLOKUN (2008). On the other hand, KOSTADINOVIĆ et al. (2015) reported that GSHPx levels were not altered by Artemisia absinthium supplementation, which is not in accordance with the results obtained in this study.

Lipid oxidation plays an important role in the deterioration of physiological functions such as growth, reproduction, and immunity, inducing higher susceptibility to infectious diseases. Malondialdehyde is used as a sensitive indicator to determine the level of oxidative stress in the organism. The determination of malondialdehyde has attracted widespread interest, since it appears to offer a simple means of assessing lipid peroxidation in biological materials (DRAPER and HADLEY, 1990). CHERIAN et al. (2013) reported that addition of Artemisia annua, also known as a sweet wormwood, had an influence on lipid oxidation products measured as TBA reactive substances (TBARS) which were lower in the breast and thigh muscle of birds fed different doses of sweet wormwood diets, compared with the control groups. The investigation of AOUADI et al. (2014) with the use of Artemisia herba alba and Rosmarinus officinalis essential oils (EOs) to evaluate the impact of the dietary administration of EOs on the overall antioxidant capacity of the muscle and on the oxidative stability of meat over a period of refrigerated storage, showed that MDA content was significantly lower in treatments treated with medical herbs in concentrations of $400 \mathrm{mg} / \mathrm{kg}$ each, compared to control treatments. On the basis of these mentioned studies it may be concluded that medical herbs play an important role in animal nutrition in terms of the oxidative stability of organisms. This was also reported by ALUWONG et al. (2013), who showed that nutrition plays a vital role in maintaining the pro-oxidant-antioxidant balance. Moreover, CAPCAROVA et al. (2010) and RAJPUT et al., (2013) noticed that some microorganisms could help in oxidation resistance, scavenge hydroxyl radicals and increase antioxidant capacity. Thus, the increased activity of all these antioxidant enzymes in the present study may be attributed to the environmental pathogens of Eimeria spp. in the rabbits. The results indicate that wormwood could improve antioxidant activities and reduce the damage caused by free radicals.

Nowadays, significantly higher attention is being paid to rabbit coccidia then earlier. Moreover, medical herbs are widely being used in different studies to treat cases of parasitism in ruminants, and enviable success has been achieved in this direction against a variety of parasites. Positive results concerning oocyst reduction were recorded in the research of KOSTADINOVIĆ et al. (2014), who reported a significant decrease in the fecal oocyst count obtained from chickens which were preventively treated with wormwood in a concentration of $3 \mathrm{~g} / \mathrm{kg}$, and subsequently infected with Eimeria spp. In research by the same authors, the reduction of the fecal oocyst count in broiler chickens fed with 


\section{S. J. Popović et al.: Artemisia absinthium: promising feed supplement in rabbits nutrition}

the addition of wormwood was about $20 \%$ compared to the positive control. The most active components in wormwood are trans-sabinene, $\alpha$ - and $\beta$-thujon, trans-sabinyl acetate, linalyl acetate and cis-chrysanthenyl acetate (BLAGOJEVIĆ et al., 2006), which are responsible for anticoccidial activity in animals. In the investigation of TARIQ et al. (2009), with the use of Artemisia absinthium against intestinal nematodes of sheep, $A$. absinthium had a positive effective against coccidisis. However, the results reported by IQBAL et al. (2013) showed that Artemisia absinthium is not so effective in reducing the fecal oocyst count in goat kids compared to commercially available anticoccidial products. RADOSTITS et al. (2007) showed that the susceptibility to coccidiostats varied, depending on the different stages of the life cycle of Eimeria spp.

\section{Conclusions}

On the basis of the results obtained numerous benefits may be noticed of supplementing the diet of rabbits with dried wormwood, without any adverse effects. Modification in rabbit nutrition led to improvement of rabbit production performances, which is related to its utilization as a natural additive. The use of wormwood could be beneficial in terms of antioxidant protection in rabbits, since the ability to activate the enzymes responsible for antioxidant protection of animals was noticed. Also, wormwood supplementation in rabbit diet led to a significant decrease in the number of oocysts per gram of feces. Given that these are preliminary results, further and more detailed investigations should be carried out in order to prove the anticoccidial effects of wormwood in rabbit diet, as well as its antioxidant activity.

\section{Acknowledgements}

The paper is a part of the research work on the project III 46012 financed by the Ministry of Education, Science and Technological Development of the Republic of Serbia.

\section{References}

ALUWONG, T., F. B. HASSAN, M. A. RAJ, M. U. KAWU, T. J., DZENDA, O. J. AYO (2013): Effect of different levels of supplemental yeast on performance indices, serum enzymes and electrolytes of broiler chickens. Afr. J. Biotechnol. 12, 5480-5485.

AOUADI, D., G. LUCIANO, V. VASTA, S. NASRI, D. M. R. BROGNA, S. ABIDI, A. PRIOLO, H. B. SALEM (2014): The antioxidant status and oxidative stability of muscle from lambs receiving oral administration of Artemisia herba alba and Rosmarinus officinalis essential oils. Meat Sci. 97, 237-243.

ASSADY, M., A., FARAHNAK, A. GOLESTANI, M. R. ESHARGHIAN (2011): Superoxide dismutase (SOD) enzyme activity assay in Fasciola spp. parasites and liver tissue extract. Iran J. Parasitol. 6, 17-22. 
S. J. Popović et al.: Artemisia absinthium: promising feed supplement in rabbits nutrition

BENZIE, I. F. (2003): Evolution of dietary antioxidants. Comp. Biochem. Physiol. A Mol. Integr. Physiol. 136, 113-126.

BIRBEN, E., U. M. SAHINER, C. SACKESEN, S. ERZURUM, O. KALAYCI (2012): Oxidative stress and antioxidant defense. World Allergy Organ J. 5, 9-19.

BLAGOJEVIĆ, P., N. RADULOVIĆ, R. PALIĆ, G. STOJANOVIĆ (2006): Chemical composition of the essential oils of Serbian wild-growing Artemisia absinthium and Artemisia vulgaris. J. Agric. Food Chem. 54, 4780-4789.

CAPCAROVA, M., J. WEISS, C. HRNCAR, A. KOLESAROVA, G. PAL (2010): Effect of Lactobacillus fermentum and Enterococcus faecium strains on internal milieu, antioxidant status and body weight of broiler chickens. J. Anim. Physiol. Anim. Nutr. 94, e215-e224.

CHERIAN, G., A. ORR, I. C. BURKE, W. PAN. (2013): Feeding Artemisia annua alters digesta pH and muscle lipid oxidation products in broiler chickens. Poultry Sci. 92, 1085-1090.

CHIU, D. T. Y., F. H. STULTS, A. L. TAPPEL (1976): Purification and properties of rat lung soluble glutathione peroxidase. Biochim. Biophys. Acta 445, 558-566.

DRAPER, H. H., M. HADLEY (1990): Malondialdehyde determination as index of lipid peroxidation. Methods Enzymol. 186, 421-431.

FEBEL, H., M. MEZES, T. PALFY, A. HERMAN, J. GUNDEL, A. LUGASI, K. BALOGH, I. KOCSIS, A. BLAZOVICS (2008): Effect of dietary fatty acid pattern on growth, body fat composition and antioxidant parameters in broilers. J. Anim. Physiol. Anim. Nutr. 92, 369-376.

HABIBI, H., S. FIROUZI, H. NILI, M. RAZAVI, S. L. ASADI, S. DANESHI (2016): Anticoccidial effects of herbal extracts on Eimeria tenella infection in broiler chickens: in vitro and in vivo study. J. Parasit. Dis. 40,401-407.

DOI: $10.1007 / \mathrm{s} 12639-014-0517-4$

HALLIWELL B., S. CHIRICO (1993): Lipid peroxidation: its mechanism, measurement and significance. Am. J. Clin. Nutr. 57, 715S-725S.

HAYES, J. D., L. I. McLELLAN (1999): Glutathione and glutathione-dependent enzymes represent a co-ordinately regulated defence against oxidative stress. Free Radic. Res. 31, 273-300.

IQBAL, A., K. A. TARIQ, V. S. WAZIR, R. SINGH (2013): Antiparasitic efficacy of Artemisia absinthium, toltrazuril and amprolium against intestinal coccidiosis in goats. J. Parasit. Dis. 37, 88-93.

KAPETANOVIĆ, I. M., I. I. MIEYAL (1979): Inhibition of acetaminophen-induced hepatotoxicaly by phenacetin and its alkoxy analogs. J. Pharmacol. Exp. Ther. 209, 25-30.

KOSTADINOVIĆ, LJ., J. LEVIĆ, S. POPOVIĆ, I. ČABARKAPA, N. PUVAČA, O. ĐURAGIĆ, S. KORMANJOŠ (2015): Dietary inclusion of Artemisia absinthium for management of growth performance, antioxidative status and quality of chicken meat. Arch. Geflügelkd. 79. DOI: $10.1399 /$ eps.2015.75

KOSTADINOVIĆ, LJ. M., I. S. ČABARKAPA, J. D. LEVIĆ, Š. M. KORMANJOŠ, S. J. TEODOSIN, S. A. SREDANOVIĆ (2014): Effect of Artemisia absinthium essential oil on antioxidative systems of broiler's liver. Food Feed Res. 41, 11-17. 


\section{S. J. Popović et al.: Artemisia absinthium: promising feed supplement in rabbits nutrition}

KOSTADINOVIĆ, LJ., Z. PAVLOVSKI, S. PAVKOV (2001): Effect of amprolium on the lipid peroxidation and the activity of superoxide dismutase in broilers blood and liver. Arch. Geflügelkd. 65, 118-122.

LANGHOUT, P. (2000): New additives for broiler chickens. World Poult. 16, 22-27.

LI, M. H., H. K. OOI (2008): Effect of chromium compounds on sporulation of Eimeria piriformis oocysts. Exp. Anim. 57, 79-83.

LUKASZEWICZ-HUSSAIN, A., J. MONIUSZKO-JAKONIUK (2004): Liver catalase, glutathione peroxidase and reductase activity, reduced glutathione and hydrogen peroxide levels in acute intoxication with chlorfenvinphos, an organophosphate insecticide. Pol. J. Environ. Stud. 13, 303-309.

MAK, D. H., S. P. IP, P. C. LI, M. K. POON, K. M. KO (1996): Alterations in tissue glutatione antioxidant system in streptozotocin-induced diabetic rats. Mol. Cell. Biochem. 162, 153-158.

MITTLER, R. (2002): Oxidative stress, antioxidants and stress tolerance. Trends Plant Sci. 7, 405410.

OLANLOKUN, J. O. (2008): Protective influence of vitamin E on the antioxidant defense system in the whole blood and liver of normal and alloxan-induced diabetic rats. Indian J. Clin. Biochem. Nutr. 23, 62-66.

OSTALOWSKA, A., E. BIRKNER, M. WIECHA, S. KASPERCZYK, A. KASPERCZYK, D. KAPOLKA, A. ZON-GIEBEL (2006): Lipid peroxidation and antioxidant enzymes in synovial fluid of patients with primary and secondary osteoarthritis of the knee joint. Osteoarthr. Cartilage 14, 139-145.

PAKANDL, M. (2009): Coccidia of rabbit: a review. Folia Parasitol. 56, 153-166.

PUVAC̆A, N., LJ. KOSTADINOVIĆ, D. LJUBOJEVIĆ, D. LUKAČ, J. LEVIĆ, S. POPOVIĆ, N. NOVAKOV, B. VIDOVIĆ, O. ĐURAGIĆ (2015): Effect of garlic, black pepper and hot red pepper on productive performances and blood lipid profile of broiler chickens. Arch. Geflügelkd. 79.

DOI 10.1399/eps.2015.73

RADOSTITS, O. M., C. GAY, K. HINCHCLIFF, P. CONSTABLE (2007): Veterinary Medicine. A textbook of the diseases of cattle, horses, sheep, pigs, and goats. Paratuberculosis (Johne's disease). $10^{\text {th }}$ ed., Saunders Elsevier, Edinburgh, London, New york, Oxford, Philadelphia, St. Louis, Sydney, Toronto, pp. 1017-1044.

RAJPUT, I. R., L. Y. LI, X. XIN, B. B. WU, Z. L. JUAN, Z. W. CUI, D. Y. YU, W. F. LI (2013): Effect of Saccharomyces boulardii and Bacillus subtilis B10 on intestinal ultrastructure modulation and mucosal immunity development mechanism in broiler chickens. Poult. Sci. 92, 956-965.

RASHWAN, A. A., I. F. M. MARAI (2000): Mortality in young rabbits: A review. World Rabbit Sci. 8, 111-124.

ROJHAN, M. (2000): Medicine and herbal treatment. $4^{\text {th }}$ ed., Tehran Alavi Press, Iran, pp. 20-22.

Vet. arhiv 87 (6), 769-782, 2017 
S. J. Popović et al.: Artemisia absinthium: promising feed supplement in rabbits nutrition

SIMON, L. M., Z. FATRAI, D. E. JONAS, B. MATKOVICS (1974): Study of peroxide metabolism enzymes during the development of Phascoulus vulgaris. Biochem. Physiol. Pflanz. 166, $387-$ 392.

SINGH, S. K., U. DIMRI, M. KATARIA, P. KUMARI (2011): Ameliorative activity of Withania somnifera root extract on paraquat-induced oxidative stress in mice. J. Pharmacol. Toxicol. 6, 433-439.

SOULSBY, E. J. L. (1982): Helminths, arthropods and protozoa of domesticated Animals. $7^{\text {th }}$ ed., ELBS and Bailliere Tindall, London, 809 pages.

STATISTICA (Data Analysis Software System) v.12.0. 2013. Stat-Soft, Inc., USA.

STEINER, T. (2009): Phytogenics in animal nutrition: Natural concepts to optimise gut health and performance. Nottingham University Press, England, 192 pages.

TARIQ, K. A., M. Z. CHISHTI, F. AHMAD, A. S. SHAWL (2009): Anthelmintic activity of extracts of Artemisia absinthium against ovine nematodes. Vet. Parasitol. 160, 83-88.

Received: 4 July 2016

Accepted: 5 July 2017

POPOVIĆ, S. J., LJ. M. KOSTADINOVIĆ, N. M. PUVAČA, B. M. KOKIĆ, I. S. ČABARKAPA, O. M. ĐURAGIĆ: Potencijal pelina (Artemisia absinthium) kao dodatak u hranidbi kunića: utjecaj na kontrolu kokcidioze, antioksidacijski sustav i proizvodna obilježja. Vet. arhiv 87, 769-782, 2017.

\section{SAŽETAK}

Cilj je ovog rada bio istražiti dodatak pelina (Artemisia absinthium) u hranidbi kunića kao potencijalni antikokcidiostatik, ali i kao promotor rasta i antioksidans. Pokus je izveden in vivo na 120 bijelih novozelandskih kunića muškog spola, a bio je ponovljen četiri puta pri čemu je formirano 10 skupina. Korištene su dvije koncentracije cijele biljke pelina: 100 g/kg (WW100) i 200 g/kg (WW200). Kunići u kontrolnoj skupini (C) bili su hranjeni smjesama bez ikakvih dodataka, dok je u hranidbi pokusnih kunića (CR) dodan kemijski kokcidiostatik robenidin u količini od $6 \mathrm{~g} / \mathrm{kg}$. Voda i hrana bili su im dostupni ad libitum tijekom cijelog pokusnog razdoblja. Utrošak hrane bio je mjeren na dnevnom razini, dok je tjelesna težina bila praćena na individualnoj razini tijekom cijelog pokusa svakih sedam dana, ukupno 77 dana. Uzorci krvi i jetre bili su prikupljeni za enzimske analize, dok je broj oocista utvrđen po $1 \mathrm{~g}$ fecesa. Na kraju ekperimenta utvrđeno je da je dodatak $200 \mathrm{~g} / \mathrm{kg}$ pelina doveo do najveće tjelesne mase kunića (3047 g) i do najmanje konverzije hrane $(3,20 \mathrm{~kg} / \mathrm{kg})$ koja se značajno razlikovala u usporedbi s kontrolom $(3,75 \mathrm{~kg} / \mathrm{kg})$. Najveća zabilježena vrijednost glutation reduktaze bila je u tretmanu WW100 sa značajnim razlikama u odnosu na druge eksperimentalne tretmane. Upotreba kokcidiostatika i osušene biljke pelina u različitim koncentracijama dovela je do znatno manjeg sadržaja malondialdehida u homogenatu jetre u usporedbi sa kontrolnim tretmanom. Također, najmanji broj oocista bio je zabilježen u tretmanu u kome je pelin dodan u koncentraciji od $100 \mathrm{~g} / \mathrm{kg}$. Na osnovi postignutih rezultata, može se primijetiti da dodatak pelina u hranidbi kunića ima pozitivan utjecaj na njihova proizvodna obilježja, kao i na antioksidacijske sustave. Također, ustanovljeno je da se pelin može uspješno koristiti za smanjivanje broja oocista.

Ključne riječi: antioksidacijski sustav, kokcidioza, proizvodna obilježja, kunić, pelin 